\title{
THE ORIGIN \\ AND OCCURRENCE \\ OF FULGURITES \\ IN THE ATLANTIC \\ COASTAL PLAIN
}

by JULIAN J. PETTY

ORIGINALLY PUBLISHED IN

AMERICAN JOURNAL OF SCIENCE

FIFTH SERIES, VOL. XXXI, NO. 183

MARCH, 1936 


\section{THE ORIGIN AND OCCURRENCE OF FULGURITES IN THE ATLANTIC COASTAL PLAIN}

by JULIAN J. PETTY

\section{ABSTRACT}

The character and field occurrence of fulgurites from the Cretaceous sands of North and South Carolina are described. Over one hundred tubes averaging about three-eighths of an inch in diameter have been collected. The tubes have been traced downward sixty feet and are surprisingly abundant in areas that could be examined in detail. The paper also includes a statement on artificial fulgurite formation and a bibliography on lightning as a geological factor.

* Paper presented in abstract at the fifteenth annual meeting of the Mineralogical Society of America, Dec. 28, 1934 


\section{INTRODUCTION}

The earliest recorded discovery of fulgurites was apparently made by Pastor David Hermann in Germany in 1706, but Voigt $(81)^{1}$ in 1805 credits a Dr. Hentzen as the first to recognize the true character of the tubes. Fiedler (31) made the first comprehensive study of them in 1817. In the United States, West (83) reported in 1843 a discovery of a fulgurite made a few years earlier in New York, and in 1861 Hitchcock (51) reports an occurrence in Massachusetts, followed in 1874 by Leeds (59) with a brief description of a fulgurite from North Carolina. Since then a number of papers on fulgurites have appeared, mostly concerned with descriptions of single occurrences or with the microscopic character of the materials. The present paper is a report, with special reference to form and field relations, of over 100 occurrences of fulgurites from the sands of the Coastal Plain of the Carolinas. A review of artificial fulgurites and a bibliography on lightning as a geological factor is added. A paper by Barrows (12) has been the source of many of the titles in the bibliography and of much help otherwise.

\section{OCCURRENCES OF Fulgurites IN THE COASTAL PlaiN}

The fulgurites collected by the writer have been obtained from nine sand pits located in Lexington, Richland, and Chesterfield Counties, South Carolina, and Moore County, North Carolina. Dr. F. H. H. Calhoun has kindly furnished a specimen collected near Wilmington, North Carolina. Other occurrences of fulgurites from the Coastal Plain have been reported by Leeds (59) at Fayetteville, North Carolina; by Merrill (60) at Sumter, South Carolina, and Santa Rosa Island, Florida; by Barrows (12), and by Myers and Peck (63) from New Jersey.

\section{MACROSCOPIC APPEARANCE OF THE TUBES}

Externally the tubes roughly resemble shriveled roots to which sand has adhered, the outer surface appearing much like the sand from which the fulgurite is formed. The internal surface, 


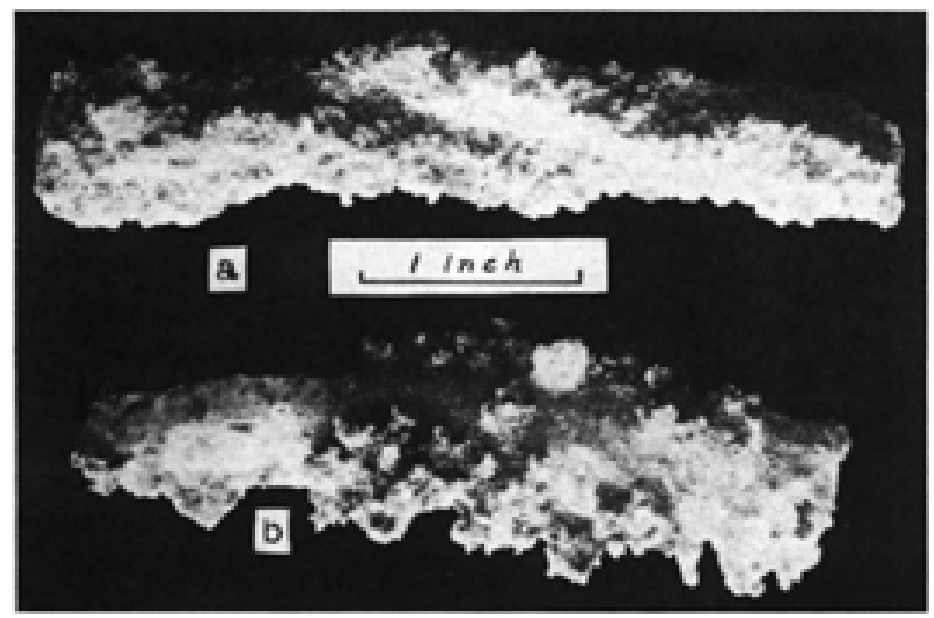

Figure 1: Fulgurites with ridged (a) and with spiny (b) surfaces

on the other hand, is smooth and of glassy appearance, with a choncoidal or botryoidal irregularity. Reentrants associated with the outside projections occur, and the inner surface as a whole may be pitted by exploded gas vesicles.

When the outside loosely adherent sand grains are removed, the fused and partly-fused portions of the tube usually present an irregular surface whose irregularity is due to either spiny projections, corrugations, keel-like lumpy ridges, or thin wing like extensions from the tube. The spiny projections may be either solid or tubular and may extend outward as much as an inch (Figs. 1b, 2a, 2c, 3a, 3b). The corrugations and wings which are often interrupted, may gradually end, and occasionally branch (Figs. 1a, 3a). The ridges, usually three or four in number, extend roughly parallel to the long axis of the tube, but as shown in Fig. 1a and reported by others $(3,14,52)$ the ridges may have a right-hand spiral twist. The wings may extend outward as much as an inch.

While the irregularity of the outer surface is commonly due to projections from the tube which often result in thickening the wall, in many instances the wall of the tube has collapsed

${ }^{1}$ Numbers in parentheses refer to the bibliography at the end of this paper. 


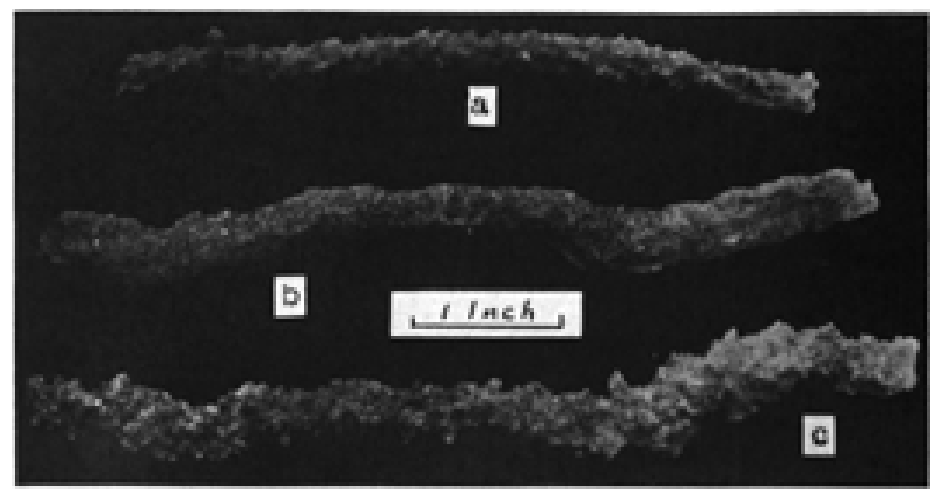

Figure 2: Fulgurites with warty $(\mathrm{a}, \mathrm{c})$ and with slightly ridged (b) surfaces

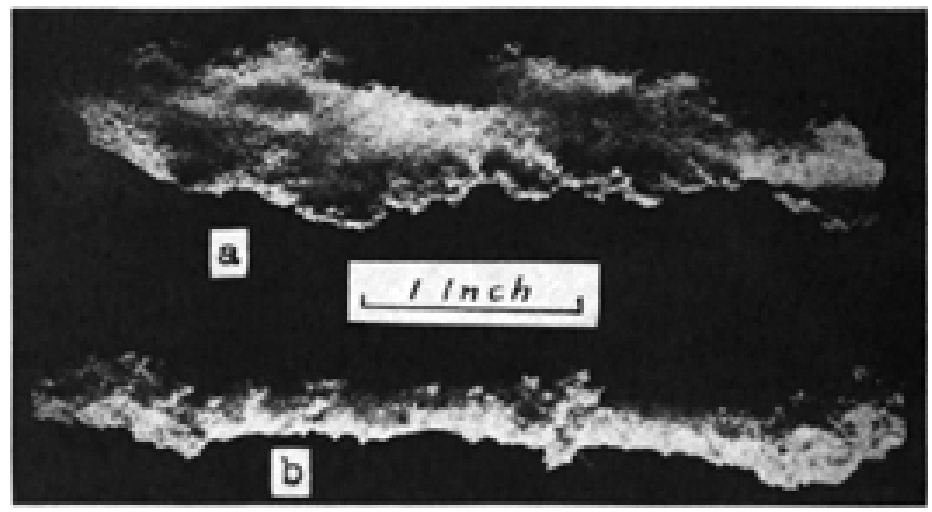

Figure 3: Fulgurites with winged projections (a) and with ring enlargements (b)

while the glass was still plastic, giving an outer surface which roughly conforms to the cross-section of the collapsed tube.

Fulgurites usually have much the same surface character for the entire length but variations within short distances also occur. There does not seem to be any marked uniformity of surface character among different tubes near each other.

Many fulgurites are made of nearly colorless glass, spotted or peppered with gray or black areas, but commonly the glass is uniformly colorless, grayish, or black.

The thickness of the wall varies from several millimeters to paper thinness, and walls of some tubes are discontinuous or 


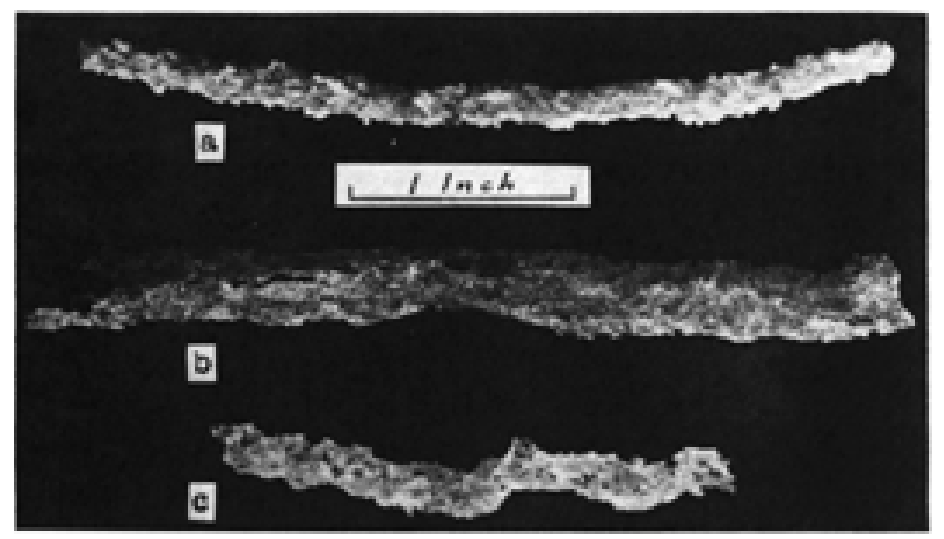

Figure 4: Fulgurites with lace-like Walls (b, c)

lace-like (Figs. 4b, 4c). No relation seems to exist between the size of the tube or its bore and the thickness of the wall, for tubes of large diameter may have thin walls.

The diameter of the fulgurites collected by the writer ranges from one-eighth of an inch to about one inch, averaging threeeighths of an inch. Tubes three inches or more in diameter have been reported (60). Considerable variation in diameter in the same tube is common, brought about by enlargement (Figs. $5 a, 5 b, 5 c, 5 d)$ or constriction of the tube, with or with out corresponding change in diameter of lumen or bore.

While downward tapering is reported, the writer has excavated a number of fulgurites 15 to 25 feet without noting any marked decrease in size.

In general the lumen is roughly circular, and conformable to the outer surface; but ridges, spines, and wings may have no corresponding interior irregularity. In many fulgurites compression of the walls took place before solidification of the glass, giving a flattened cross-section. Compression may be limited to a portion of a tube, and in closely adjacent fulgurites one may be compressed and the other not. In several instances where tubes paralleled the inclined bedding planes of the enclosing sand, cross-sections were found to be oval or rectangular, with short axis normal to the bedding planes. While not evident from the photograph, Fig. $4 \mathrm{~b}$ is oval in section. 


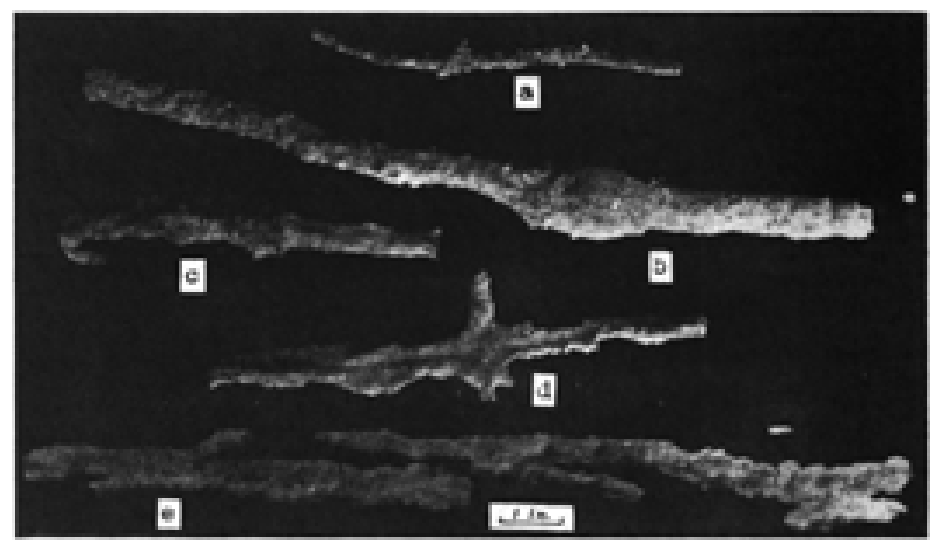

Figure 5: Fulgurites with tube enlargements (a, b, c, d) and a tube (e) which branches and the branches reunite

\section{LENGTH AND POSITION OF THE TUBES}

Fulgurites 20 to 30 feet in length are common in the areas examined by the writer and tubes as much as 60 feet below the surface of the sand have been collected from the Foster pit at Dixiana, South Carolina. While the tubes usually follow a tortuous though roughly vertical downward course through the sand, variations of this course are worthy of note.

Many tubes branch and rebranch, with outward divergence of the branches, or occasionally the branches may follow nearly parallel courses for a few inches and reunite as shown in Fig. 5e.

In some fulgurites, apparently limited to the smaller tubes, the course parallels the bedding of the sand. For the larger tubes inclined positions, either for parts of the course or all of it, without any definite relation to the bedding of the sand occur. Barrows (12) reports a tube running at an angle of ten degrees to the horizontal for the entire length recovered. A large tube found by the writer was nearly vertical except for four inches where it followed a horizontal course, the change from vertical to horizontal and from horizontal to vertical being accomplished by right angle turns. 
A zone of reddish sand, usually less than one-quarter of an inch thick, though occasionally three or four inches (69), commonly surrounds the fused material. In passing downward, due to dissipation of energy associated with the lightning discharge, smaller and smaller amounts of sand are fused, forming discontinuous walled tubes, or merely reddish streaks in the sand. The fusion may end abruptly when a conducting or wet layer is encountered. The bulbous terminating sacks reported from Nebraska (10) have not been found in the Coastal Plain.

\section{OCCURRENCE}

Because of their fragility, fulgurites are usually found only where the sand has not been much disturbed; thus they are seldom found in cultivated fields. In areas where the soil is lacking or has been removed, a small amount of erosion leaves the tubes projecting or pieces lying on the surface. These conditions commonly occur where the overburden has been removed and on slopes into sand pits.

The sand pits from which the writer's collections of fulgurites have been made are located in the Cretaceous sediments which outcrop in a broken fringe of hilly topography along the inner margin of the Coastal Plain. Sand, clay, and gravel make up the formation, but the sand pits are generally located where the sands are thick and clay lenses thin or lacking. The sands are fine to coarse in texture, composed mostly of quartz, and commonly crossbedded.

The pits from which the largest collections have been made are most actively operated and frequently examined. The following table summaries the collections made from the pits.

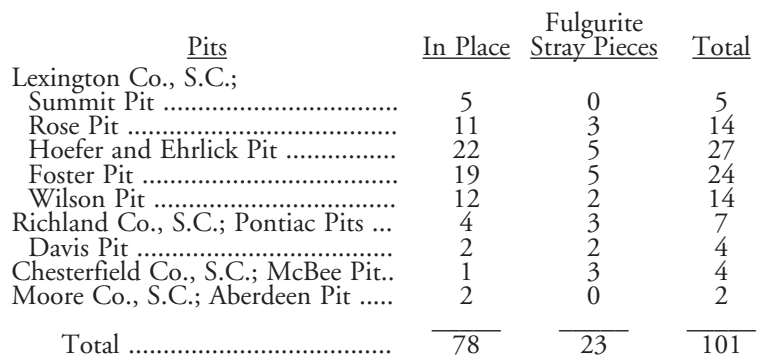


The total area of the pits examined would amount to several hundred acres, but in each pit only a small part of the total area is favorable for the discovery of fulgurites. A density of several fulgurites per acre is thus indicated for the areas examined. The fact that fulgurites occur in all the pits examined, together with the wide distribution of the pits suggests that fulgurites are common throughout the Sand Hill Belt.

\section{ORIGIN OF TUBES}

It is a matter of common observation that lightning frequently strikes the earth's surface; but only where the surface materials are sandy are sand fulgurites formed. Many observers $(23,53$, $54,64,78,79,80,82)$ have noted the surface markings and killing of vegetation by lightning.

Lacroix $(57,58)$ has pointed out that in the Pyrenees rocks rich in iron minerals appear more susceptible to being struck by lightning, and exposed points such as mountain peaks, are known to be more frequently struck. Neither of these factors can explain the abundance of fulgurites in the Coastal Plain, since the Sand Hills are not outstanding topographic features, nor is the composition of the sands exposed in the pits such as to attract or conduct lightning.

Three factors without doubt play an important part in causing the abundance of fulgurites in the Coastal Plain. The purity of the sand together with the good drainage which keeps the sand relatively dry, results in favorable conditions for fulgurite formation when lightning strikes. Also the formation of fulgurites has probably taken place over a long period of time.

The length of the tubes depends on the intensity of the lightning discharge and the thickness of the sand layer, which acts as a dielectric. A discharge of low intensity may be gradually dissipated in the sand while one of high intensity may pass through many feet of sand before the discharge is grounded. The groundwater table or a wet stratum determines the downward limit of fulgurite formation.

The path followed by the lightning through the sand is in general like the path of lightning in the atmosphere between 
cloud and earth, some discharges following a single path and other discharges following branching and rebranching paths, in each case the discharges follow the paths of least resistance. Most irregularities of the course in the ground are no doubt due to differences in resistance to passage of the discharge resulting from changes in composition, moisture content, compaction, etc., of the sand. Thus inclined bedding may divert the course, as has been observed for several smaller tubes. Small differences in conductivity would probably be of greater influence for the smaller discharge than the larger discharge.

The occurrence of fulgurites in groups was long ago explained by Darwin (25) as being due to the branching and rebranching of lightning before reaching the ground. Several fulgurites in line may be a result of shifting of the point of strike due to drift of path of discharge with the wind.

Three explanations of the tubular form of the fulgurite have been offered: Either the lumen is due to expansion of the moisture present in the sand, or it is due to the expansion of the air along the path of the discharge, or it results from a mechanical thrusting aside of the sand which is then fused around the hole made. As there is theoretically no mechanical force associated with the passage of an electrical discharge, the opening made must be due to expansion of air and moisture, and in dry sand largely the expansion of air, along the path of the discharge. The amount of sand melted depends on the energy expended in the form of heat, the melted material taking a cylindrical shape due to surface tension. The diameter of the tube is determined by the amount of expansion of air and moisture along the path of the discharge which, when great in proportion to sand melted, produces a large-bored thin-walled tube. The collapse of some tubes before solidification of the glass is probably related to length of time during which discharge takes place, i.e., the rate at which energy is dissipated, and ease of relief of expansive force, since a short timed discharge produces quick expansion and release of pressure before congealing of melted material. Swellings in the tubes may be due to less resistance to expansion by the wall material or to greater porosity allowing larger amounts of air and moisture in the sand. Obviously dif- 
ference in composition of the sand would influence the amount of sand melted.

Fielder (33) long ago noted that the tubes were broken before excavation, often into smaller pieces for the thicker walled tubes, and he accounted for this fracturing by shrinkage of the glass on cooling. No doubt settling of the sand and earthquake tremors account for some of the fracturing. In most instances the tubes suffer additional fracture while being excavated. The longest piece the writer has recovered is about 14 inches.

\section{ARTIFICIAL FULGURITES}

The first serious experiments on the production of artificial fulgurites were carried out by Rollman (70) in 1868, although experiments had been made as early as 1828 (15). In 1909 Butcher (22) made tubes up to $9.5 \mathrm{~mm}$. long and $0.5 \mathrm{~mm}$. in diameter by passing a spark through powdered glass and resin placed in a hole in a block of paraffin wax. The conclusions were that the tubes result from fusion around a column of air in which the spark passes; that the length and thickness of the tube depends on the energy and character of the spark; that the difference between thick- and thin-walled tubes was probably due to a difference in the sharpness of the flash and the resulting explosive effect, which effect, when great and the quantity of material melted small, produces a large-bored thin-walled tube.

As far as known no subsequent systematic experimentation in the production of artificial fulgurites has been carried out. This is unfortunate, considering the fact that now electric discharges of much greater energy content can be produced, even approaching actual lightning conditions. A systematic investigation should reveal the influence of composition of sand, size of sand grain, moisture content, and many other varying conditions on the character of the artificial fulgurite, and through comparison of the artificial fulgurites with those produced by lightning, much information about the lightning discharges which strike sand might be learned. 


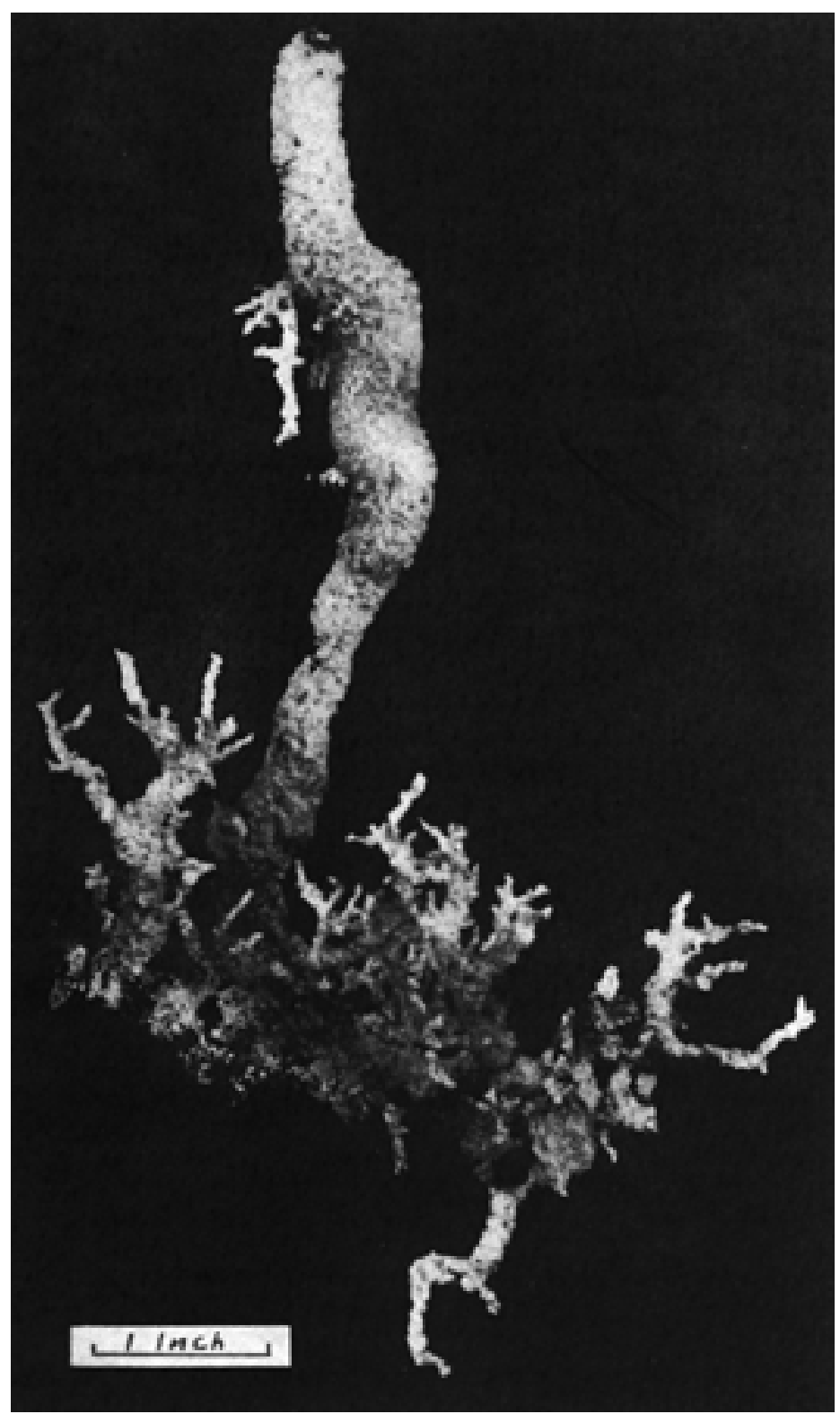

Figure 6: Artificial fulgurite made by passing electric current into grounded tenquart pail of sand. (Courtesy General Electric Company, Pittsfield, Mass.) 
A few artificial fulgurites have been made by the General Electric Company by passing high voltage discharges into sand. Mr. K. B. McEachron has kindly furnished a photograph (Fig. 6) of one artificial fulgurite they made by passing the current from an electrode suspended over a grounded ten quart pail filled with a fairly clean mixture of quartz and feldspar.

Occasionally when high tension wires are grounded conditions are favorable for the production of artificial fulgurites. Mr. E. B. Eckel has given the writer information about the production of fulgurites ranging from one-tenth of an inch to three inches in thickness and up to two and one-half feet in length, which were formed when a high tension wire came in contact with the ground, thereby causing a current to discharge into granitic debris for about 12 hours near Boulder, Colorado.

\section{BIBLIOGRAPHY}

1. Abbe, C. Lightning Strokes in Open Field: Mo. Weather Rev., vol.32, p.323, 1904.

2. Abich, Hermann. Die Fulguriten im Andesit des kleinen Ararat: Sitb. der Math.-Nat. Classe der K. Ak. der Wiss, Wien, vol. 60,pp. 153-161, 1869.

3. Anderson, A. E. Sand Fulgurites from Nebraska, their Structure and Formative Factors: Nebr. State Museum, Bull. 7, vol. 1, pp. 49-86, 1925.

4. Andersson, Gunnar. An Example of Lightning as a Geological Factor:(Swedish) Geol. For. Stockholm Fordhandlungar, vol. 23, pp. 521-526, 1901.

5. Anon. On the Vitreous Tubes found near to Drigg in Cumberland: Trans. Geol. Soc. London, vol. 2, pp. 528-532, 1814.

6. - . On the Vitreous Tubes at Drigg: Trans. Geol. Soc. Lon don, vol. 5, pp. 6176181821.

7. A Rare Collection of Fulgurites: Princeton Alumni Weekly, vol. 9, pp. 152-153, 1908.

8. Arago. Sur des Tubes vitreux que paraissent produits par des coups de Foudre: Ann. de Chim. et de Phys., vol. 19, pp. $290-$ 303, 1821. 
9. Aston, E., and Bonney, F. G. On an Alpine Nickel-bearing Ser pentine with Fulgurites: Quart. Jour. Geol. Soc., vol. 52, pp. 452-460, 1896.

10. Barbour, E. H. Notes on Nebraska Fulgurites: Nebr. State Museum,Bull. 6. vol. 1, pp. 45-48, 1925.

11. Barnett, V. H. An Example of Disruption of Rock by Lightning on One of the Leucite Hills in Wyoming: Jour. Geol., vol. 16, pp. 568-571, 1908.

12. Barrows, W. L. A Fulgurite from the Raritan Sands of New Jersey with an Historical Sketch and Bibliography of Fulgu rites in General: Sch. Mines Quart., vol. 31, pp. 294319, 1910.

13. Bastelaer, D. A. Van. Sur un Fulgurite forme en presence de plusieurs temoins a Gougnies pres de Charleroi: Bull. Acad. Roy. des Sci. Bruxelles, vol. 6, 3d Ser., pp. 144$152,1883$.

14. Bayley, W. S. A Fulgurite from Waterville, Me.: This Journal, vol. 43, pp. 327-328, 1892.

15. Beudant, Hachette and Savart. Experience sur la Formation des Tubes fulminaires: Ann. de Chim. et de Phys., vol. 37, pp. 319-321, Ann. der Phys., vol. 89, pp. 117-118, 1828.

16. Berg, H. Blitzrohrenfund in Krummendorf bei Rostock: Arch. Nat. Meckl., vol. 59, pp. 214-217, 1905.

17. Berthier. Examen d'un enchantillon de sable recueilli par M.

Fielder autour du Fulgurite de Dresde: Comptes Rendus de l'Acad. des Sci. vol. 17, pp. 598-599, 1843.

18. Bonney, J. G. Fulgurites from Tupungato and the Summit of Aconcagua: Geol. Mag., vol. 6, pp. 1-4, 1899.

19. Bottiger. Einiges aus dem Alterthume uber die Blitzröhren: Ann. der Phys., vol. 72, pp. 317-322, 1822.

20. Bruckmann, U. F. B. Von den sogenannten Blitzrohren aus der Sennerheyde im Lippeschen: Voigt's Mag. fnr den neuesten Zust. der Natk., vol. 11, pp. 64-67, 1806.

21. - Von den sogenannten Blitzstein oder pierre foudroyee am Mont Blanc: Voigt's Mag. fur den neuesten Zust. der Natk., vol. 11, pp. 67-68, 1806. 
22. Butcher, Dorothy D.. Experiments on artificial Fulgurites: Proc. Phys. Soc. London, vol. 21, pp. 254-260, 1909.

23. C. F. B. Lightning Holes: Mo. Weather Rev., vol. 47, p. 729, 1920.

24. Cook, H. J.. Manganese Fulgurites: Nebr. State Museum, Bull. 5, vol. I pp. 41-44, 1925.

25. Darwin, Charles. (Fulgurites from Maldonado. South America): Voyage of H. M. S. Beagle, Appleton, pp. 59-62, 1895.

26. Dauzere, C., and Bouget, J. Recherches sur le foudre dans les Pyrenees: C. R. Congres Soc. Savantes, 1925; Also Bull. de l'Institute et Observatorie de Physique du Globe du Pic du Midi, Toulouse, 1928.

27. Delesse and de Lapparent. Fulgurite: Ann. de Milles, vol. 8, pp. 700-702, 1875.

28. Desvaux, N. A. Des Stalctites souterraines ou pretendues Fulgu rites: Angers Mem. Soc. Agric., vol. 1, pp. 109-121, 1831.

29. Diller, J. S. Fulgurite from Mt. Thielson, Oregon: This Journal vol. 28, pp. 252-258, 1884.

30. . On a Fuigurite from Mt. Thielson, Oregon: Science, vol. 3, pp. 735-736,1884.

31. Fielder, Karl Gustav. Uber die Blitzrohren und ihre Enstehung: Ann. der Phys., vol. 55, pp. 121-164, 1817.

32. - Uber die Blitzrohren und ihre Enstehung (Ein Nachtrag): Ann. der Phys., vol. 61, pp. 235-248, 1819.

33. Neuer Fundort der Blitzrohren: Ann. der Phys., vol. 68 pp. 209-211, 1821.

34. - Auffingdung und Ausgrabung einer 8 Leipzig Ellen 5 3/4 Zoll langen Blitzrohren bei Dresden: Ann. der Phvs. vol. 71, pp. 301-302, 1822.

35. - . Auffingdung und Ausgrabung einer Blitzrohre im Konigreiche Ungarn bis an ihre Ende: Ann. der Phys., vol. 74, pp. 213-217, 1823.

36. - (Fulgurite found in a Vineyard near Dresden): Comptes Rendus de l'Acad. des Sci., vol. 17, pp. 215-216, 1843.

37. Fredholm, K. A. Another Example of Lightning as a Geological Factor: (Swedish) Geol. For. Stockholm fordhandlingar, vol. 24 pp. 283-284, 1902. 
38. Geinitz, E. Uber eine Blitzrohre aus der Ribnitzen Heide: Arch. Nat. Meckl. vol. 47, pp. 60-67, 1893.

39. . Blitzrohren von Liessow und Goldberg: Arch. Nat. Meckl., vol. 56, pp. 188-192. 1902.

40. Gilbert, Ludwig Wilhelm. Noch einiges von den Blitzrohren: Ann. der Phys., vol. 61, pp. 249-262, 1819.

41. - Ein Nachtrag zu dem Aufsatze von den Blitzrohren: Ann. der Phys., vol. 61, pp. 315-316, 1819.

42. - Noch einiges von Blitzrohren und von Wirkungen des Blitzes auf Felsenstucke: Ann. der Phys., vol. 71, pp. 337-344, 1822.

43. Gourdon, M. Fulgurites: La Feuille des Jeunes Naturalistes, vol. 26, pp. 57 and 81, 1895-1896.

44. Green, A. H. (Fulgurite at Macclesfield, England): Geol. Surv. of Great Britain Memoir to accompany sheets 81 N.W. and 81 S.W. pp. 76-77, 1866.

45. Gumbel. Uber Fulgurite: Zt. der D. Geol. Gesell., vol. 34, pp. 647-648, 1882.

46. - Uber Fulgurite: Zt. der D. Geol. Gesell., vol. 36, p. 179, 1884

47. Hagen. Bericht von der Bildung einer Blitzrohre durch den Blitz, am17ten Juli, 1823, zu Rauschen in Ostpreussen: Ann. der Phys., vol. 74, pp. 325-330, 1823.

48. Hallock, W. Peculiar Effects due to a Lightning Discharge on Lake Champlain in August, 1900: Jour. Geol., vol. 9, pp. 671-672, 1901.

49. Harting, M. P. Notice sur un cas de formation de Fulgurites et surla presence d'autres Fulgurites dans le Sol de la Neerlande: Acad. Roy. Neer. des Sci., 1874.

50. Hills, R. C. Fulgurite from the Spanish Peaks: Proc. Colo. Sci. Soc. vol. 3, pp. 280-287, 1891.

51. Hitchcock. (Note on finding of Fulgurite at Northfield Farms, Mass.): This Journal, vol. 31, p. 302, 1861.

52. Hobbs, W. H. A Spiral Fulgurite from Wisconsin: This Journal, vol. 8, pp. 17-20, 1899.

53. Johnston, E. E. Lightning Injury to Potato Field: Mo. Weather Rev., vol. 48, p. 452, 1921. 
54. Jones, L. R., and Gilbert, W. W. Lightning Injury to Cotton and Potato Plants: Mo. Weather Rev., vol. 43, p. 135, 1915; Also Phytopathology, no. 6, p. 406, 1914.

55. Julien, A. A. A Study of the Structure of Fulgurites: Jour. Geol., vol. 9, pp. 673-693, 1901.

56. Lacroix, A. La silice foudre consideree comme mineral (Lechatelierite): Bull. Soc. fr. Min., vol. 38, pp. 182$186,1915$.

57. _ - Sur les fulgurites exclusivement siliceuses du Sahara ori ental et sur quelque fulgurites silicates des Pyrenees: Bull. Soc. fr. Min., vol. 38, pp. 188-189, 1915; Abst. Rev. du Geol., vol. 2, pp. 183-184, 1921.

58. - Nouvelles observations sur les fulgurites exclusivement siliceuses du Sahara: Bull. Soc. fr. Min., vol. 54, pp. 7579, 1931 Abst. Rev. du Geol., vol. 12, p. 442, 19311932.

59. Leeds, A. R. Fulgurite near Fayetteville, N. C.: Acad. Nat. Sci. Philadelphia, Proc., p. 145, 1874.

60. Merrill, G. P. On Fulgurites: U. S. Nat. Museum, Proc. 9, pp. 83-91, 1886.

61. - Fulgurites or Lightning Holes: Pop. Sci. Monthly, vol. 30, pp. 529-539, 1887.

62. Montigny, Ch. Rapport sur le travail de D. A. Van Bastelaer intitule "Notice sur un Fulgurite, etc.": Bull. Acad. des Roy. des Sci. Bruxelles, vol. 6, 3d Ser., pp. 129-130, 1883.

63. Myers, W. M., and Peck, A. B. A Fulgurite from South Amboy, N. J.: Amer. Mineral., vol. 10, pp. 152-155, 1925; .Abst. Pan-Am. Geol., vol. 44, pp. 159-160, 1925.

64. Payne, F. F. Ground Markings by Lightning: Mo. Weather Rev. vol. 56, p. 216, 1928.

65. Pfaff, C. H. Beobachtete Enstehung eine Blitzrohre durch den Blitz: Ann. der Phys., vol. 72, p. lli, 1822.

66. Planeth, H. Eine in Mecklenburg gefundene Blitzrohre: Arch. des Ver. der Freunde der Natg. in Mecklenburg, vol. 33, pp. 307-311, 1879. 
67. Poggendorf, J. C. Auffingdung von Blitzrohren in der

Africanischen Wuste: Ann. der Phys., vol. 86, pp. 483486, 1827.

68. Richardson, J. E. Fulgurites: Mineral. Collector, III, pp. 131135, 145-151, 161-166, 1896-1897.

69. Roemer, Ferd. Uber ein Vorkommen VOI1 Blitzrohren oder Fulguriten bei Starczynow unveit Olkusz im Konigreiche Polen: N. Jahrb. fur Min., pp. 33-40, 1876.

70. Rollman, W. Uber die kuntsliche Herstellung von Blitzrohren: Ann. der Phys., vol. 134, pp. 605-615, 1868.

71. Rose, G. (Exhibition of rock Fulgurite from Ararat and Mexico) In Protokoll der November Sitzung, Zt. der D. Geol. Gesell., vol. 25 pp. 112-113, 1872.

72. Rutley, Frank. On Fulgurite from Mt. Blanc: Quart. Jour. Geol. Soc., vol. 41, pt. 2, pp. 152-154, 1885.

73. - On Fulgurites from Monte Viso: Quart. Jour. Geol. Soc., vol. 45, pp. 60-66, 1889.

74. Sainter. (Fulgurite from Macclesfield, England): Geol. Mag. Lon don. vol. 2, p. 368, 1865.

75. Saussure, Horace-Benedict. Voyages dans les Alpes: vol. 4, pp. $472-$ 478, Geneva, 1786.

76. Scholz, C. Zur Kenntniss der Fulgurite: Archiv der Pharmacie, vol. 3, pp. 541-543, 1873; Polytechnisches Jour., vol. 211, p. 408, 1874; Ann. Record of Sci. and Ind., p. 228,1874 .

77. Shipton, W. D. A Note on Fulgurites from Sparta, Wis.: Iowa Acad. Sci., Proc. 23, p. 141, 1916.

78. Simson, A. G. Note on the Effect of a Lightning Bolt: Mo. Weather Rev., vol. 58, p. 467, 1930.

79. Steven, A. F. Lightning explodes Tree and digs Trenches: Mo. Weather Rev., vol. 49, pp. 241-242, 1922.

80. Talmage, S. B. Spoor of a Thunderbolt: Sci. Monthly, vol. 28, pp. 368-374, 1929.

81. Voigt, J. K. W. Nachricht von den Blitzrohren: Voigt's Mag. fur den neuesten Zust. der Natk., vol. 10, pp. 491-495, 1805.

82. Weightman, R. H. Lightning Branches on the Ground: Mo. Weather Rev., vol. 62, pp. 200-201, 1934. 
83. West, C. E. Notice of certain Siliceous Tubes (Fulgurites) formed in the Earth: This Journal vol. 45, pp. 220-222, 1843.

84. Wichmann, Arthur. Uber Fulgurite: Zt. der D. Geol. Gesell., vol. 35, pp. 849-859, 1883.

85. Wicke, Wilhelm. Directe Beobachtungen uber Enstehung von Blitzrohen: Ann. der Phys., vol. 106, pp. 158-159, 1859.

86. Withering, Wm. An Account of some extraordinary Effects of Lightning: Phil. Trans. Roy. Soc. London, pp. 293-295, 1790.

UNIVERSITY OF SOUTH CAROLINA, Columbia, S. C. 


\section{THE EVENT}

PETRIFIED LIGHTNING FROM CENTRAL FLORIDA

A Project by Allan McCollum

CONTEMPORARY ART MUSEUM

UNIVERSITY OF SOUTH FLORIDA

$\overline{\text { MUSEUM OF SCIENCE AND INDUSTRY }}$

TAMPA, FLORIDA 